\title{
Polyaromatic hydrocarbons, chlorinated and brominated organic contaminants as tracers of feeding ecology in polar benthic amphipods
}

\author{
Tore C. Svendsen ${ }^{1}$, Lionel Camus ${ }^{2}$, Barry Hargrave ${ }^{3}$, Aaron Fisk ${ }^{4}$, \\ Derek C.G. Muir ${ }^{5}$, Katrine Borga ${ }^{6, *}$ \\ ${ }^{1}$ Department of Environmental Chemistry and Microbiology, National Environmental Research Institute, \\ Frederiksborgvej 399, 4000 Roskilde, Denmark \\ ${ }^{2}$ Akvaplan-niva AS, Polar Environmental Centre, 9296 Tromsø, Norway \\ ${ }^{3}$ Department of Fisheries and Oceanography, Bedford Institute of Oceanography, PO Box 1006, Dartmouth, \\ Nova Scotia B2Y 4A2, Canada \\ ${ }^{4}$ University of Windsor, 401 Sunset Avenue, Windsor, Ontario N9B 3P4, Canada \\ ${ }^{5}$ National Water Research Institute, Environment Canada, PO Box 550, Burlington, Ontario L7R 4A6, Canada \\ ${ }^{6}$ Norwegian Institute for Water Research, Gaustadalléen 21, 0349 Oslo, Norway
}

\begin{abstract}
Concentrations of organochlorines (OCs) such as polychlorinated biphenyls (PCB), dichloro-diphenyl-trichloroethane (DDT), hexachlorocyclobenzene (HCB), chlordanes, and hexachlorocyclohexanes (HCHs) were measured in 3 different species of benthic marine amphipods (Eurythenes gryllus, Anonyx nugax, and Paramphitoe hystrix) from 4 different locations: 2 from the Canadian Arctic and 2 from the Norwegian Arctic. In addition, polycyclicaromatic hydrocarbons (PAHs) and brominated flameretardants (BFR) such as polybrominated diphenyl ether (PBDE) and hexabromocyclododecane (HBCD) were measured in E. gryllus from the Norwegian Arctic. For all species and locations, concentrations of OCs in the amphipods were higher than those found in zooplankton and other benthic organisms from the same areas. If the amphipods' OC concentrations were determined by sediment exposure, their values would be close to other benthic infauna, suggesting that sediment exposure does not explain the amphipods' higher OC concentrations. In fact, the OC concentrations in benthic amphipods were similar to those in seals and gulls, which provides strong evidence that benthic amphipods are scavengers of higher trophic level carrion. Concentrations of PBDE and PAH were also high in E. gryllus ( $\mathrm{PPBDE} 115$ to $493 \mathrm{ng} \mathrm{g}^{-1}$ lipid weight [lw]; $\Sigma \mathrm{PAH}$ $\left.269 \mathrm{ng} \mathrm{g}^{-1} \mathrm{lw}\right)$, and were in the same range as measured in marine animals. BFR concentrations correlated with PCB and DDT concentrations (PCBs: $\mathrm{r}^{2}=0.61 \mathrm{p}<0.0076$; DDTs: $\mathrm{r}^{2}=0.530 \mathrm{p}<0.0171$ ), indicating the same bioaccumulation potential. BFRs are thereby emerging problems as their concentrations increase in Arctic regions.
\end{abstract}

KEY WORDS: Arctic - Benthic amphipods - Organochlorines - Scavenger - PCB - DDT - PBDE · $\mathrm{HBCD} \cdot \mathrm{PAH}$

\section{INTRODUCTION}

Chlorinated organic contaminants (OCs) have been found in the Arctic for 4 decades (Bowes \& Jonkel 1975, Vorkamp et al. 2004). Agricultural and industrial use of OCs in the Arctic regions has been limited, and the chemicals are transported to the Arctic areas from distant sources by the atmosphere and oceans (Macdonald et al. 2000). Most OCs are hydrophobic and accumulate in lipid-rich tissues of biota at levels far exceeding those in the abiotic environment (AMAP 1998). Due to predator-prey transfer as well as slower elimination than uptake rates, OC concentrations increase with trophic level 
in the food web, leading to high concentrations in top predators (Muir et al. 1999).

OC levels increase exponentially in the food web (Broman et al. 1992), whereby small invertebrates with a relatively short life span usually have much lower OC concentrations than vertebrate predators located at higher trophic levels. However, studies on the benthic amphipod Eurythenes gryllus from the Canadian Arctic in the late 1980s revealed OC concentrations in the range found in marine mammals and seabirds (Hargrave et al. 1992, Bidleman et al. 1993). Benthic organisms with a close association to the sediment often have higher OC concentrations than pelagic organisms at the same trophic level, due to high affinity of the OCs to the sediment particles and thereby transport from the water column to the sea floor (Bright et al. 1995). However, the OC levels in benthic E. gryllus were unexpectedly high, especially when compared with other benthic organisms such as the blue mussel Mytilus edulis (Christensen et al. 2002). A recent study from the Canadian Arctic confirmed high OC levels in another benthic amphipod, Anonyx nugax (Fisk et al. 2003). These high OC levels may have resulted from scavenging upon carcasses of marine mammals with high levels of OC, and these benthic amphipods could perhaps be compared with top predators regardless of their small size (Hargrave et al. 1992, Bidleman et al. 1993, Fisk et al. 2003). Unfortunately, limited information is available on the feeding ecology of these benthic amphipods, and only few studies have been conducted to investigate feeding dynamics and behavior in E. gryllus and other carrion-feeding species (Hargrave 1985, Sainte-Marie 1992, Hargrave et al. 1994, 1995). An understanding of OC accumulation in benthic amphipods would add to the knowledge of their role in marine food web dynamics.

Earlier studies on benthic amphipods focused on OCs such as polychlorinated biphenyls (PCBs) and chlorinated pesticides. Bioaccumulation of other compounds, such as brominated contaminants, is of interest, particularly because concentrations of polybrominated diphenyl ethers (PBDEs) have increased in recent years in the Canadian Arctic (Ikonomou et al. 2002). Polycyclic aromatic hydrocarbons (PAHs) have also begun to receive more attention because their concentrations may be increasing in the environment due to the expansion of oil and gas activities into the Arctic regions.

The main aim of the present study was to investigate if selected benthic amphipods from the Arctic region are scavengers, as inferred from the distribution of contaminant types and amounts. The first objective of this study was to compare levels and patterns of OC contaminants among 3 different benthic Arctic amphipods (Eurythenes gryllus, Anonyx nugax and
Paramphitoe hystrix) sampled from 4 sites in 2 different Arctic regions (Canadian and Norwegian Arctic). The second objective was to determine if OC levels can be used as dietary tracers to better understand the feeding behavior of these benthic amphipods. Finally, the third objective was to evaluate the bioaccumulation potential of emerging pollutants such as PBDEs and PAHs in comparison with the legacy OCs such as PCBs.

\section{MATERIALS AND METHODS}

Species description and sampling. Many benthic amphipods are carrion feeders (Oliver \& Slattery 1985, Hargrave et al. 1992, Sainte-Marie 1992). The micropredator Paramphitoe hystrix is found on deep-sea sponges and carrion (Schnabel \& Herbert 2003), while Eurythenes gryllus is a motile scavenger that lives in both these benthic habitats as well as in the water column (Charmasson \& Calmet 1987, Hargrave et al. 1995). Anonyx nugax is a common Arctic species that is both necrophagous and carnivorous (Legeżyńska 2001, Węslawski \& Legeżyńska 2002).

The benthic amphipods Eurythenes gryllus and Paramphitoe hystrix were collected northeast of Svalbard (NOS) and from the Yermak Plateau (YP) in September 2002 and 1999, respectively (Table 1). P. hystrix was collected with a bottom trawl at about $570 \mathrm{~m}$, whereas E. gryllus was collected with a deep-sea trawl at about $100 \mathrm{~m}$. Anonyx nugax was obtained from the Canadian Arctic in Resolute Bay (RB) and Barrow Strait using traps with protected bait deployed at depths of 5 to $100 \mathrm{~m}$ between July and October 1993, and from Northern Baffin Bay (NBB) in July 1998 from a depth of $\sim 500 \mathrm{~m}$ using protected baited traps. Animals were handled and sorted using solvent-rinsed stainless steel forceps (Table 1). Specimens were pooled into separate samples (1 to $5 \mathrm{~g}$ wet weight) (Table 1 ) with the exception of E. gryllus, which were analyzed individually and stored frozen $\left(-18\right.$ to $\left.-20^{\circ} \mathrm{C}\right)$ in solvent-rinsed glass or polypropylene containers before OC analysis.

Chemical analysis. Several OCs were analysed in the amphipods, but only results from OCs measured in all samples are included in the comparison of species and area (Table 1): these included $\alpha, \beta$ and $\gamma$ - hexachlorocyclohexane (HCHs), trans-nonachlor, oxychlordane, 3 dichloro-diphenyl-trichloroethane compounds $\left(p, p^{\prime}\right.$-DDE, $p, p^{\prime}$-DDD, $p, p^{\prime}$-DDT [DDTs]), hexachlorocyclobenzene (HCB) and 8 PCB congeners (CB 31/28, CB 52, CB 99, CB 118, CB 138, CB 153 and CB 180).

The quantification of OCs in Anonyx nugax from RB was carried out at Axys Analytical Services (Sydney $\mathrm{BC}$, Canada) using high resolution gas chromatography (HRGC)/low resolution mass spectrometry (LRMS) 
Table. 1. Eurythenes gryllus, Paramphitoe hystrix and Anonyx nugax. Concentrations $( \pm$ SD) of lipids, HCH, HCB, transnonachlor, oxychlordane DDT, and PCB in samples of benthic amphipods from 4 locations. $\Sigma \mathrm{HCH}^{\mathrm{i}}$ sum of $\alpha-$, $\beta-$ and $\gamma-\mathrm{HCH}_{i} \Sigma \mathrm{DDT}$ is sum of $p, p^{\prime}$-DDD, $p, p^{\prime}$-DDE and $p, p^{\prime}$-DDT; $\Sigma$ PCB is the sum of PCBs 28, 31, 52, 99, 118, 138, 153, and 180. lw: lipid weight

\begin{tabular}{|c|c|c|c|c|}
\hline \multirow[t]{2}{*}{ Location } & \multirow{2}{*}{$\begin{array}{c}\text { Eurythenes gryllus } \\
\text { Northeast of Svalbard (NOS) }\end{array}$} & \multirow{2}{*}{$\begin{array}{l}\text { Paramphitoe hystrix } \\
\text { Yermale Plateau (YP) }\end{array}$} & \multicolumn{2}{|c|}{ Anonyx nugax } \\
\hline & & & Northern Baffin Bay (NBB) & ) Resolute Bay (RB) \\
\hline $\mathrm{n}(\mathrm{N})$ & $10(1)$ & $3(6)$ & $5(5-10)$ & $14(5-10)$ \\
\hline Sampling date & 22 Sep 2002 & 29 Sep 1999 & 4-7 Jul 1998 & 19 May-21, Oct 1993 \\
\hline Depth (m) & 100 & 576 & $2-600$ & $5-100$ \\
\hline Method & Deep-sea trawl & Bottom trawl & Baited trap & Baited trap \\
\hline Lipid content (\%) & $10.2 \pm 4.2$ & $5.0 \pm 1.1$ & $2.5 \pm 0.7$ & $3.4 \pm 0.9$ \\
\hline$\Sigma \mathrm{HCH}\left(\mathrm{ng} \mathrm{g}^{-1} \mathrm{lw}\right)$ & $7.0 \pm 0.9$ & $357 \pm 132$ & $348 \pm 258$ & $1339 \pm 860$ \\
\hline $\mathrm{HCB}\left(\mathrm{ng} \mathrm{g}^{-1} \mathrm{lw}\right)$ & $83 \pm 64$ & $197 \pm 14$ & $63 \pm 52$ & $96 \pm 56$ \\
\hline EDDT (ng g $\left.{ }^{-1} \mathrm{lw}\right)$ & $5753 \pm 5617$ & $1836 \pm 721$ & $158 \pm 30$ & $297 \pm 227$ \\
\hline$\Sigma$ PCB $\left(\right.$ ng g $\left.^{-1} \mathrm{lw}\right)$ & $4175 \pm 3865$ & $1424 \pm 566$ & $311 \pm 199$ & $327 \pm 273$ \\
\hline Trans-nonachlor ( $\mathrm{ng} \mathrm{g}^{-1} \mathrm{lw}$ ) & $1068 \pm 1062$ & $522 \pm 71$ & $110 \pm 35$ & $118 \pm 93$ \\
\hline Oxychlordane (ng $\left.\mathrm{g}^{-1} \mathrm{lw}\right)$ & $11.8 \pm 3.9$ & $5.3 \pm 1.0$ & na & $1.6 \pm 1.4$ \\
\hline
\end{tabular}

on a Finnigan INCOS 50 mass spectrometer equipped with a Varian 3400 GC, a CTC autosampler and a DG10 data system running INCOS 50 (Rev 11) software. HRGC/HRMS analyses were performed on an Ultima AutoSpec HRMS equipped with a Hewlett Packard 5890 C. A Hewlett Packard 5890 GC with a ${ }^{63} \mathrm{Ni}$ electron capture detector (ECD) was used for $\mathrm{GC} / \mathrm{ECD}$ analyses of the PCBs.

The quantification of OCs in A. nugax from NBB was carried out at the Freshwater Institute (FWI), Winnipeg, MB, Canada. This laboratory was taking part in inter-laboratory calibration exercises as part of the Canadian 'Northern Contaminants Program' (NCP) when the analyses for this study were conducted (Stokker 2000, 2001). Samples were freeze-dried, spiked with an internal standard $\left(2,2^{\prime}, 3,4,4^{\prime}, 5,6,6^{\prime}\right.$ octachlorobiphenyl [CB 204] and octachloronaphthalene) and extracted with dichloromethane (DCM): hexane (1:1 ratio) using a Dionex ASE 200 accelerated solvent extractor (Dionex Canada). Following extraction, a fraction of the extract was used to determine lipids gravimetrically. Lipids were removed from the sample by gel permeation chromatography (GPC). The lipid-free eluate containing the OCs was evaporated to $1 \mathrm{ml}$ and applied to a Florisil ( $8 \mathrm{~g}, 1.2 \%$ deactivated) column. OCs were recovered by consecutive elution with $35 \mathrm{ml}$ hexane, $38 \mathrm{ml} \mathrm{85 \%} \mathrm{hexane:15 \%} \mathrm{DCM} \mathrm{and}$ $50 \mathrm{ml}$ DCM:hexane. For the subsequent silica gel clean-up, OCs were separated into 2 fractions: Fraction 1 (eluted with $65 \mathrm{ml}$ hexane) contained $100 \%$ of the PCB congeners, along with chlorobenzene isomers and $o, p^{\prime}$ - and $p, p^{\prime}$-DDE, while Fraction $2(90 \mathrm{ml}$ DCM:hexane) containied chlordane-related compounds, HCH isomers, and other DDT-related compounds. All fractions were rotary evaporated, transferred to 2,2',4-trimethylpentane and evaporated to approximately $100 \mu \mathrm{l}$. Aldrin was added as a volume corrector to all samples. Samples $(100 \mu \mathrm{l})$ were analyzed on a Varian (Palo Alto) 3600 GC equipped with a $60 \mathrm{~m} \times 0.25 \mathrm{~mm} \mathrm{DB}-5$ column $(\mathrm{J} \& \mathrm{~W}$ Scientific) and ECD, with $\mathrm{H}_{2}$ as the carrier gas. $\mathrm{N}_{2}$ was used as the make-up gas for the ECD. External standards were run after every 6 samples. Standard recoveries of CB30 and OCN for all samples were $75.6 \pm 2.3$ (mean $\pm 1 \mathrm{SE}$ ) and $76.5 \pm 2.1$, respectively. Concentrations were not corrected for recoveries. Standard reference materials (NIST 1588a cod liver oil) were run and were within $20 \%$ of certified values. Results for OC pesticides and PCB congeners were within $30 \%$ of consensus values agreed upon as part of NCP inter-laboratory exercises (Stokker 2000, 2001).

The quantification of OCs in Paramphitoe hystrix was carried out at the Environmental Toxicology Laboratory at the Norwegian School of Veterinary Science, Oslo, Norway, as described in detail by Borgå et al. (2002), with minor modifications of the methods described by Brevik (1978) and Bernhoft \& Skaare (1994). Homogenized samples were added to internal standard (CB 29, 112, 207), and extracted with cyclohexane and acetone. The extracts were divided for gravimetric lipid determination and clean-up of lipid by sulfuric acid. OCs in the lipid-free extract were separated by a HRGC (Agilent 6890 Plus GC system, Agilent Technologies) with 2 fused silica capillary columns of different polarity (SPB-5 and SPB-1701; $60 \mathrm{~m}, 0.25 \mathrm{~mm}$ i.d., $0.25 \mu \mathrm{m}$ film; Supelco) and an ECD.

The quantification of $\mathrm{OCs}$, brominated flame retardents (BFR) and PAH in Eurythenes gryllus was carried out at the National Laboratory for Environmental Testing (NLET) at the National Water Research Insitute (NWRI), Burlington, ON, Canada, using analytical methods described by Johansen et al. (2004). In brief, samples were homogenized prior to extraction and recovery standards of 1,3,5-bromobenzene, 1,2,4,5- 
tetra-bromobenzene, $\delta$ - $\mathrm{HCH}$, endrin ketone, CB 30 and CB 204 were added. Homogenized tissue was mixed with pre-cleaned sodium sulfate to form a dry powder, and Soxhlet-extracted with DCM for $6 \mathrm{~h}$. The extract was applied to the top of a GPC column to remove lipids using DCM:hexane (1:1 ratio) as the elution solvent. Extractable lipids were determined gravimetrically in the first $150 \mathrm{ml}$ of GPC eluate by evaporating off the solvent. The GPC eluate was reduced to a small volume, quantitatively exchanged into hexane and chromatographed on activated Silica Gel $(8 \mathrm{~g}$ in a $1.1 \mathrm{~cm}$ diameter chromatographic column) to separate PCBs (Fraction 1) from other compounds including chlorinated bornanes (toxaphene), PBDEs and PAHs. Fraction 2 from the silica gel column was analysed separately for PBDEs, hexabromocyclododecane (HBCD) and toxaphene by GC-electron capture negative ion (low resolution) mass spectrometry without further clean-up. PCB congeners and OC pesticides were determined by GC-ECD using a $30 \mathrm{~m} \times 0.25 \mathrm{~mm}, 0.25 \mu \mathrm{m}$ film thickness DB-5 column. The quantification was carried out using a series of external standards of guaranteed purity from the supplier. PBDEs and HBCD were quantified using an external standard consisting of 32 congeners. Gas chromatographic conditions for the analysis of BFR were described by Luross et al. (2000). As discussed by Verreault et al. (2005), any $\beta$ and $\gamma$-HBCD residues in the samples were most likely thermally isomerized to $\alpha-\mathrm{HBCD}$ and/or degraded in the GC injection port; thus, our results represent total HBCD. Both silica column fractions were combined for the analysis of PAHs. Samples were injected into a GCMS in electron-ionization mode and detected by selected ion monitoring. The PAHs were quantified using a multi-point calibration, internal standard method. Instrument conditions were described by Environment Canada (1998). The samples were analysed for the following PAHs: naphthalene, 2-methylnaphthalene, 1 -methylnaphthalene, $\beta$-chloronaphthalene, acenaphthylene, acenaphthene, dibenzothiopene, fluorene, phenanthrene, anthracene, fluoranthene, retene, ryrene, benzo(a)anthracene, chrysene, benzo(b)fluoranthene, benzo(k)fluoranthene, benzo(e)pyrene, benzo(a) pyrene, perylene, indeno(123cd)pyrene, dibenz(ah)anthracene, benzo(ghi)perylene.

In total, Eurythenes gryllus was analyzed for 35 OC pesticides, 104 PCB congeners, 15 BFRs and 22 PAHs. To ensure good reproducibility and correct measurements, the chemical analysis included method blanks and certified reference material (National Institute of Standards and Technology [NIST]: cod liver 1588a) with each batch of 10 to 12 samples, as well as calculation of surrogate recoveries for each sample. Results for chlorinated pesticides and PCBs in NIST 1588a were within $30 \%$ of certified values.
All the chemical analyses was performed at accredited laboratories, and the different samples were all within the quality criteria of the individual laboratories presented above. Furthermore, the laboratories all used certified reference material to test their analysis.

Data analysis. The multivariate ordination technique principal component analysis (PCA) was chosen to analyze how the OCs co-varied among the samples (regarding OC inter-correlation), and also to reduce the dimensions of response variables in order to analyze if there was a structure in the variance that could be explained by species identity or sampling area. PCA was performed on absolute concentrations and standardized concentrations (pattern of relative concentrations) using CANOCO 4.5 for Windows (Ter Braak \& Smilauer 1998), and included only those OCs quantified in all species: CB 31/28, CB 52, CB 99, CB $118, \mathrm{CB} 153, \mathrm{CB} 138, \mathrm{CB} 180, \alpha-\mathrm{HCH}, \beta-\mathrm{HCH}, \gamma-\mathrm{HCH}$, $\mathrm{HCB}$, oxychlordane, trans-nonachlor, $p, p^{\prime}-\mathrm{DDE}, p, p^{\prime}-$ DDD and $p, p^{\prime}$-DDT. To compare absolute concentrations of OCs among the samples, the OC concentrations were logarithmically transformed prior to analysis to limit variance heterogeneity and skewness. The effect of lipid content on OC concentration was accounted for by including lipid as a co-variable.

The PCA extracts ordination axes that minimize the total residual sum of squares among all the response variables (here OCs), and assigns scores to the individual samples that are linear combinations of the OCs. The individual OCs are presented as arrows pointing to the direction of increasing absolute or standardized value in the PCA of concentrations or pattern, respectively. The angles between arrows indicate correlations (or co-variance) between the OCs: a small angle means high correlation, whereas a $90^{\circ}$ angle means that the OCs' occurrence in the samples is not correlated.

The relative composition of the different OC groups in amphipods was compared with that of the ringed seal Phoca hispida (data from Fisk et al. 2002) (see Fig. 2). This comparison was conducted by investigating the contribution of individual compounds to the total amount of the 3 groups DDT, PCB and HCHs.

Eurythenes gryllus was the only amphipod where individual specimens were analyzed (Table 1). For $E$. gryllus, $\Sigma \mathrm{PCB}, \Sigma \mathrm{DDT}, \Sigma \mathrm{PBDE}$ and $\Sigma \mathrm{PAH}$ were regressed onto the measured length of the animals to investigate the influence of size (and thereby age) on the accumulated contaminant level. The linear regression was carried out using Graph Pad Prism version 4.03 for Windows. The inter-correlation among concentrations of $\Sigma \mathrm{PCB}, \Sigma \mathrm{DDT}, \Sigma \mathrm{BFR}$ and $\Sigma \mathrm{PAH}$ in individual $E$. gryllus was analyzed by a parametric correlation analysis. 

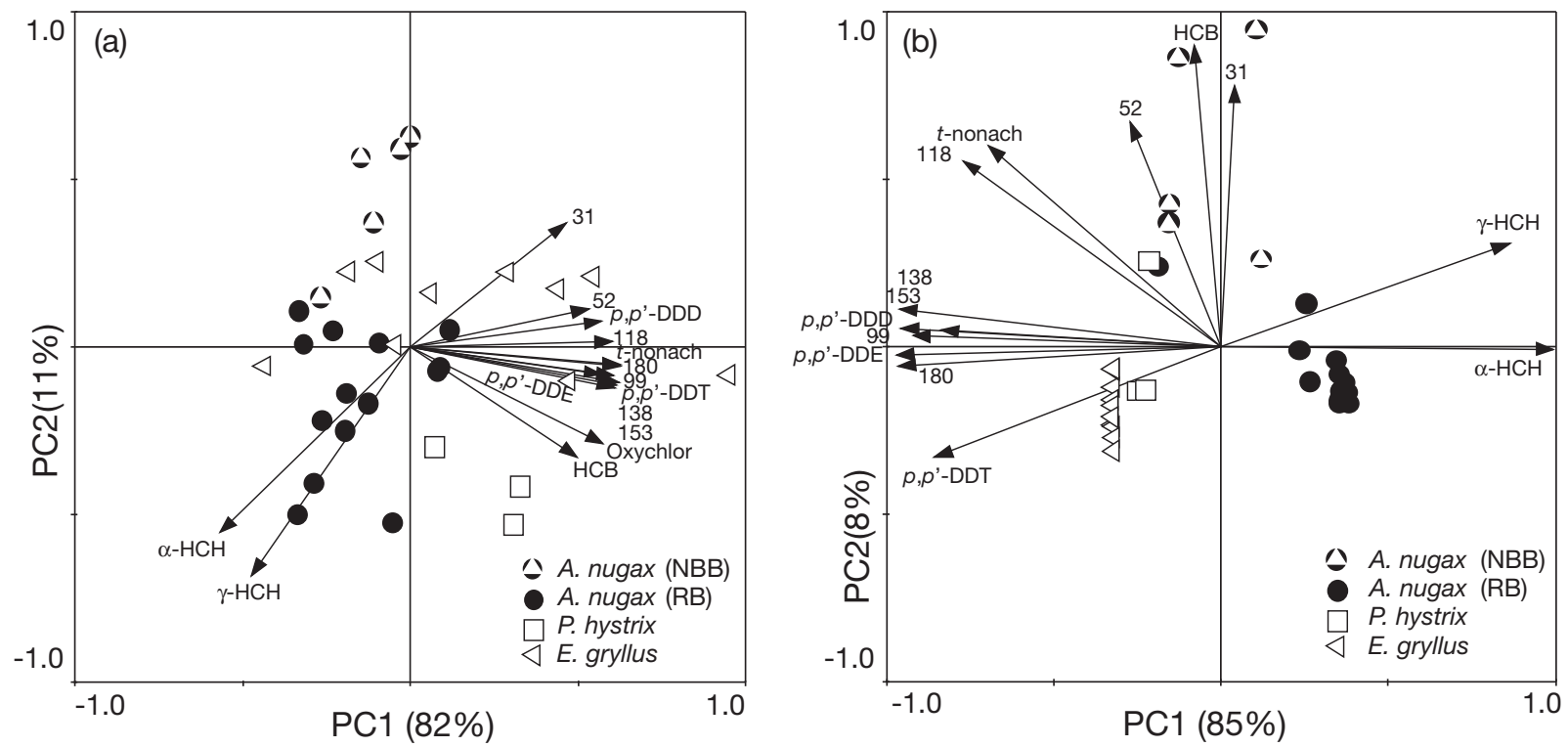

Fig. 1. Eurythenes gryllus, Paramphitoe hystrix and Anonyx nugax. PCA of organochlorines (OCs) in benthic amphipods. (a) Absolute concentrations. (b) Standardized concentrations. Numbers refer to respective PCB congener

\section{RESULTS}

Differences in seasonal sampling time, sampling year and analytical methods can lead to dissimilarities in results that must be considered when data from different studies are merged. A review of data was therefore conducted prior to data analysis to avoid the effects of these differences in our data set. While different amphipods were collected in different years, only samples from mid-May to mid-October were included due to possible changes in the concentration during the year as seen for e.g. zooplankton (Hargrave et al. 2000). Seasonal effects within this time period were accounted for by including fat content as a covariable. Only chemicals measured above the detection limit in all samples were considered. These criteria and the use of accredited laboratories should have ensured the comparability among studies.

\section{Legacy OCs in benthic amphipods}

OC concentrations were high in all the benthic amphipods (Table 1). Eurythenes gryllus had the highest $\Sigma$ DDT and $\Sigma$ PCB concentrations, whereas Anonyx nugax (RB) had the highest $\Sigma \mathrm{HCH}$ concentrations. $\Sigma \mathrm{DDT}$ and $\Sigma \mathrm{PCB}$ concentrations increased from western $(A$. nugax; RB) to eastern locations (E. gryllus) and the opposite pattern was observed for $\mathrm{\Sigma HCH}$.

PCA of absolute concentrations separated Eurythenes gryllus and Paramphitoe hystrix from Anonyx nugax along PC1, which accounted for $82 \%$ of the total variation (Fig. 1a). This separation was due to high concentrations of DDTs and PCB congeners and low concentration of $\mathrm{HCH}$ isomers in E. gryllus and P. hystrix, and low PCB in combination with high $\mathrm{HCH}$ concentration in A. nugax. E. gryllus exhibited large variation in OC concentration, and therefore the samples did not group but were instead widely distributed along PC1 (Fig. 1a). The variation in OC concentrations among E. gryllus samples was not related to differences in size $\left(\mathrm{r}^{2}=0.1122 \mathrm{p}<0.3442\right)$. Along PC2, which accounted for $11 \%$ of the total variation, $P$. hystrix separated from E. gryllus due to a higher concentration of HCB and HCHs in the former. A. nugax separated along $\mathrm{PC} 2$ due to a higher $\mathrm{HCH}$ concentration in $\mathrm{RB}$ amphipods and higher $\mathrm{CB} 31$ concentrations in NBB amphipods.

Even though the OC concentrations varied between the different localities and species (Table 1, Fig. 1a), the relative composition (pattern) of each OC group was generally similar among the species (Fig. 2), with some exceptions: among the different DDTs. $p, p^{\prime}$-DDE was dominant, while $p, p^{\prime}$-DDD only represented a very limited proportion of $\Sigma$ DDTs. Because $p, p^{\prime}$-DDT is converted to $p, p^{\prime}-\mathrm{DDE}$, the ratio of $p, p^{\prime}-\mathrm{DDE}$ to $p, p^{\prime}-$ DDT indicates the history of pollution, with the ratio increasing with temporal or spatial distance from source (Lee et al. 2000). The ratio $p, p^{\prime}$-DDE: $p, p^{\prime}$-DDT was lower in the Canadian Arctic than in the Norwegian Arctic (Anonyx nugax [RB] 0.30; A. nugax (NBB) 0.50; Paramphitoe hystrix 0.81; Eurythenes gryllus 0.67 ), indicating a newer (or closer) source in the Canadian Arctic. A relatively similar $\Sigma$ PCB composition was 


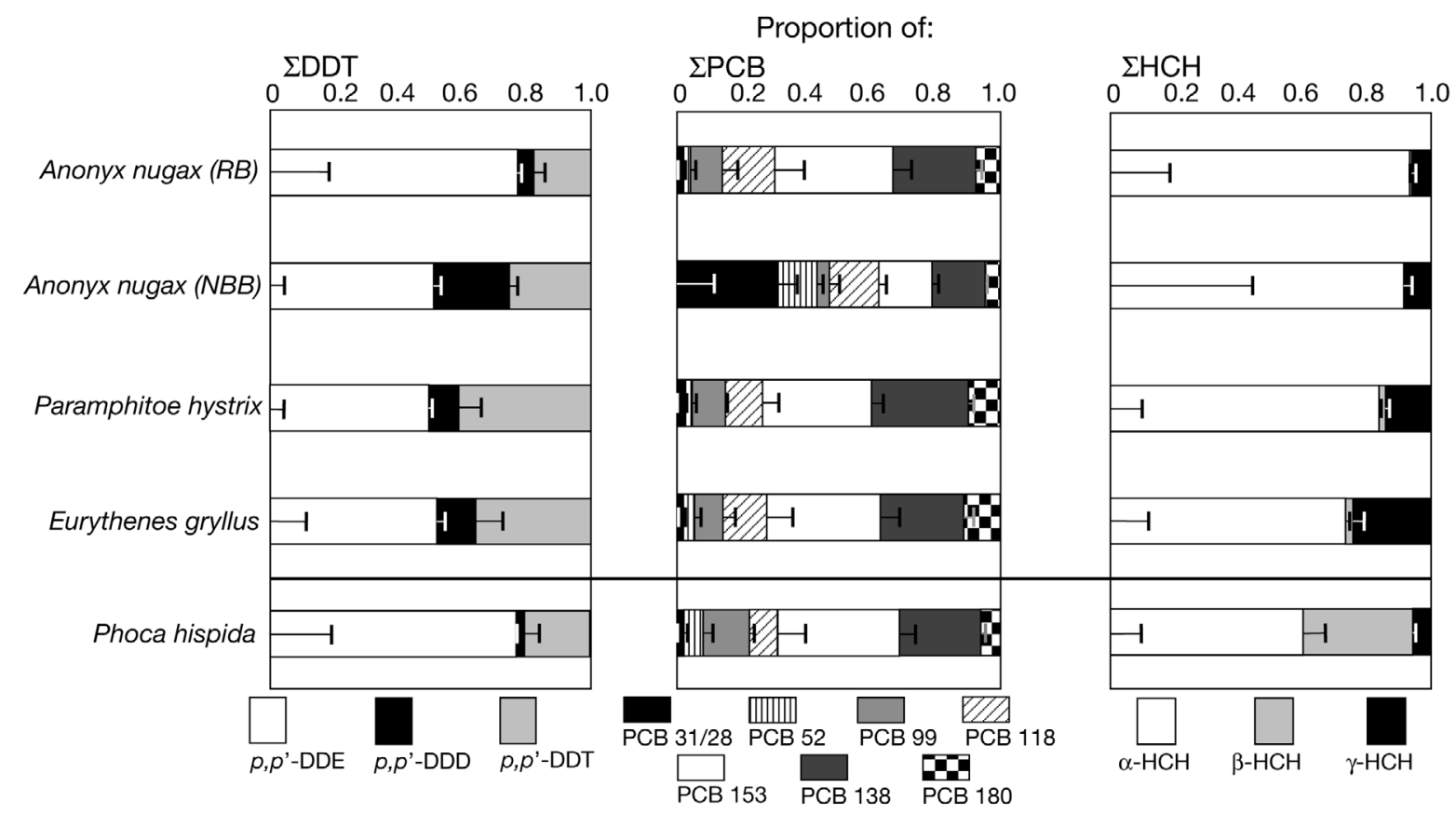

Fig. 2. Eurythenes gryllus, Paramphitoe hystrix and Anonyx nugax. Relative contribution of individual compounds to $\Sigma$ DDTs, $\Sigma$ PCBs and $\Sigma \mathrm{HCHs}$ in benthic amphipods from Canadian and Norwegian Arctic. For comparison, the relative distribution found in the ringed seal Phoca hispida is included (Fisk et al. 2002). Error bars are SE

found among P. hystrix, E. gryllus and A. nugax (RB), whereas A. nugax (NBB) differed from the other species. Whereas CB 153 and CB 138 dominated the $\Sigma$ PCB pattern in A. nugax (RB), E. gryllus, and P. hystrix, CB 31 was the predominant $\Sigma$ PCB in A. nugax (NBB). Even when $C B 31$ was removed from the data sets, the relative $\mathrm{PCB}$ composition of the remaining $\Sigma \mathrm{PCBs}$ was dissimilar between $A$. nugax (NBB) and the other amphipods (results not shown). CB 153 accounted for $\sim 25 \%$ of the remaining $5 \mathrm{PCBs}$ in $A$. nugax (NBB) and $\sim 35 \%$ in the other amphipods. $\alpha-\mathrm{HCH}$ dominated the $\Sigma \mathrm{HCH}$ in all species, while $\beta-\mathrm{HCH}$ was not found in $A$. nugax (NBB) and was only observed in low concentrations in A. nugax (RB).

On the whole, there was no large difference between the OC patterns of amphipods and the ringed seal (Fig. 2); however, there were some exceptions, e.g. $\beta-\mathrm{HCH}$. $\beta-\mathrm{HCH}$ was present in low relative concentrations in amphipod tissues, while it amounted to $16 \%$ of $\Sigma \mathrm{HCH}$ in ringed seal (Fisk et al. 2002). As in Anonyx nugax (RB), $p, p^{\prime}$-DDE represented $80 \%$ of the $\Sigma$ DDT in ringed seal.

When combining results from the PCA of absolute OC concentrations (Fig. 1a) with the relative composition within each OC group (Fig. 2), it is clear that the large concentration difference among amphipod samples, especially for Eurythenes gryllus, masks the patterns of OCs among the amphipods. To investigate this, PCA was carried out on standardized concentrations, including all OCs quantified in all amphipods
(Fig. 1b). Regardless of the difference in PCB and DDT pattern between Anonyx nugax NBB and RB, all $A$. nugax samples were separated from the other samples because of a high relative contribution of $\mathrm{HCHs}$ and a lower contribution of chlorinated PCBs and DDT. The differences in patterns of $A$. nugax PCB congener distribution between $\mathrm{RB}$ and $\mathrm{NBB}$, with elevated relative contributions of $\mathrm{CB} 31, \mathrm{CB} 52$, in addition to elevated HCB in A. nugax (NBB), compared with A. nugax (RB), lead to a separation along PC2. Although samples of $E$. gryllus exhibited large variations in absolute concentrations (Fig. 1a), the pattern of OCs among samples shows little variation (Fig. 1b).

The OC pattern in the 2 amphipod species from the Norwegian Arctic (Eurythenes gryllus and Paramphitoe hystrix) was similar to those of the other 2 groups of amphipods. An exception to this is one P. hystrix sample that grouped with A. nugax (NBB). This sample also differed from the other $P$. hystrix samples in terms of enantiomeric fractions of chiral chlorinated pesticides (Borgå \& Bidleman 2005), which remains unexplained.

\section{Levels of brominated flame retardents and PAHs in Eurythenes gryllus}

Of the 15 brominated flame retardents (BFR) analyzed in Eurythenes gryllus, 12 PBDEs and HBCD were quantified (PBDE 17, 28/33, 47, 66, 71, 85, 99, 
$100,138,153,154,209$ and HBCD), with $\Sigma$ BFR ranging from 115 to $493 \mathrm{ng} \mathrm{g}^{-1}$ lipid weight (lw) (mean $\pm \mathrm{SD}$ : $303 \pm 137 \mathrm{ng} \mathrm{g}^{-1} \mathrm{lw}$; median: $271 \mathrm{ng} \mathrm{g}^{-1} \mathrm{lw}$ ). The BFRs were clearly dominated by PBDE 47 , which accounted for $60 \%$ of the total contents of flame retardants. Three other flame retardents accounted for the $31 \%$ (HBCD: 15\%; PBDE 100: $8 \%$; PBDE 99: $8 \%$ ), while the remaining 10 congeners equally comprised the last $9 \%$
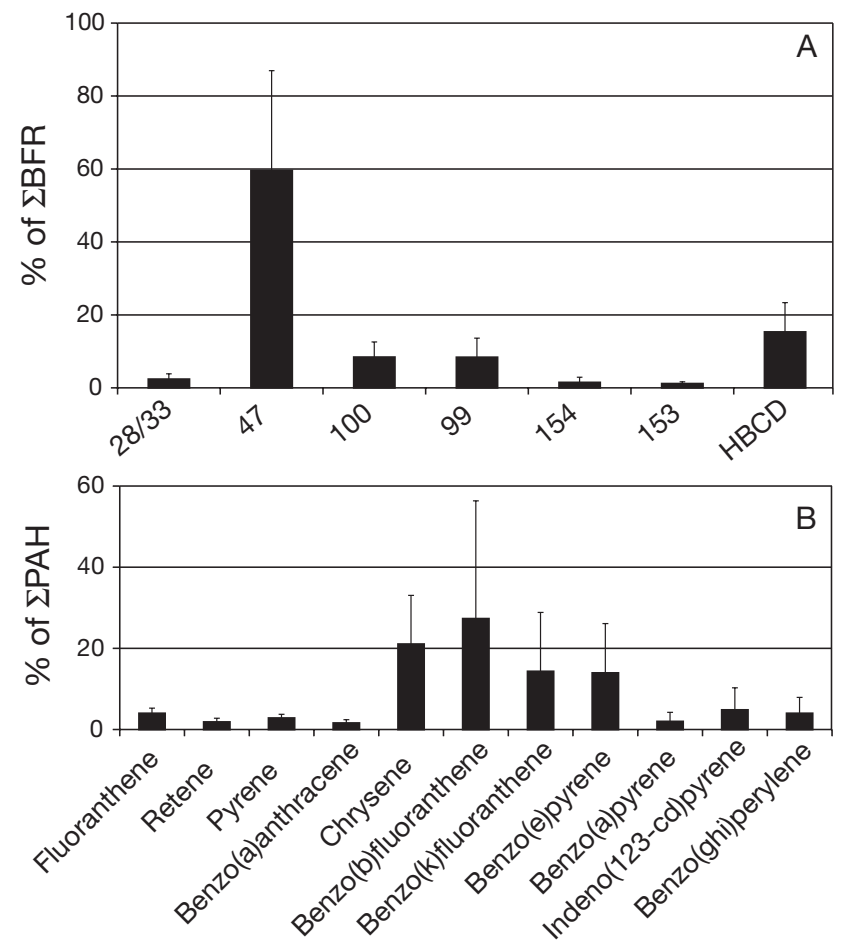

Fig. 3. Eurythenes gryllus. Composition of (A) BFR (PBDE congeners and HBCD) and (B) PAHs. Only components contributing $>1 \%$ to the sum of the respective group are shown. Error bars are SE

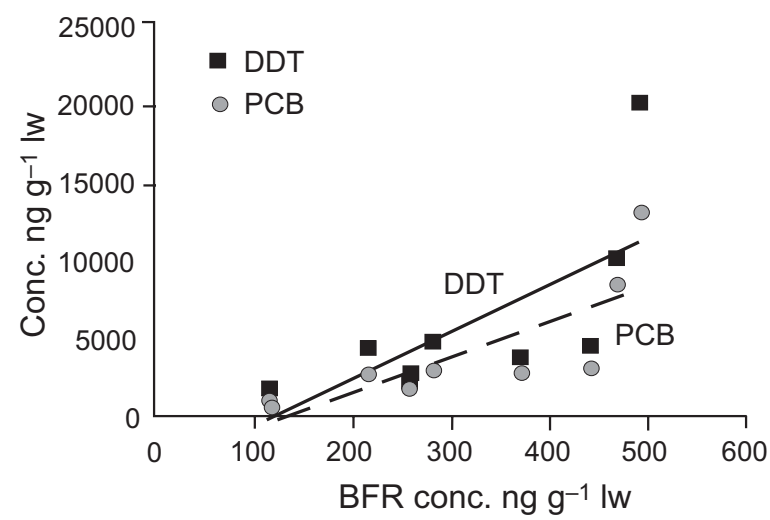

Fig. 4. Eurythenes gryllus. Comparison of $\Sigma \mathrm{BFR}, \Sigma \mathrm{DDT}$ and $\Sigma$ PCB concentrations. $\Sigma$ BFR vs. $\Sigma$ DDT: $\mathrm{r}^{2}=0.530, \mathrm{p}<0.0171$ (solid line); $\Sigma$ BFR vs. $\Sigma$ PCB: $\mathrm{r}^{2}=0.611, \mathrm{p}<0.0076$ (dashed line)
(Fig. 3). $\Sigma$ BFR concentrations were approximately 10 times lower than PCB concentrations. $\Sigma$ BFR was positively correlated with $\Sigma$ DDT $\left(\mathrm{r}^{2}=0.53, \mathrm{p}<0.0171\right)$ and $\Sigma$ PCB $\left(\mathrm{r}^{2}=0.61, \mathrm{p}<0.0076\right)$ (Fig. 4).

Twenty-two different PAHs were quantified in Eurythenes gryllus, with $\Sigma \mathrm{PAHs}$ ranging from 583 to $4583 \mathrm{ng} \mathrm{g}^{-1} \mathrm{lw}$ (mean \pm SD: $269 \pm 222 \mathrm{ng} \mathrm{g}^{-1} \mathrm{lw}_{\text {; }}$ median: $206 \mathrm{ng} \mathrm{g}^{-1} \mathrm{lw}$ ). Four PAHs dominated the $\Sigma$ PAH [benzo(b)fluoranthene $34 \%$; benzo(k)fluoranthene $17 \%$; chrysene $14 \%$; benzo(e)pyrene $14 \%$ ], while the remaining were more evenly distributed (Fig. 3). $\Sigma$ PAH was not significantly correlated with either $\Sigma$ DDT $\left(\mathrm{r}^{2}=0.3581, \mathrm{p}<0.0676\right)$ or $\Sigma \mathrm{PCB}\left(\mathrm{r}^{2}=\right.$ $0.3737, \mathrm{p}<0.0604)$. Neither $\Sigma$ PBDE nor $\Sigma$ PAHs concentrations were related to the amphipod's size $\left(r^{2}=\right.$ $0.2443, \mathrm{p}<0.192 ; \mathrm{r}^{2}=0.1473, \mathrm{p}<0.233$ ).

\section{DISCUSSION}

\section{OCs in arctic benthic amphipods}

The OC concentrations in all amphipod species from all regions investigated in the present study were generally high, especially when compared with levels found in sessile invertebrates such as blue mussels Mytilus edulis from the east coast of Greenland (Cleemann et al. 2000). If all benthos were equally and predominantly exposed to OC accumulation from the sediment, then the levels should be comparable despite the different feeding strategies. However, elevated levels in benthic amphipods support earlier suggestions of a source of contaminants that differs from that to which the other benthic animals are exposed (Hargrave et al. 1992, Bidleman et al. 1993, Fisk et al. 2003).

This source is likely to be a pelagic dietary source, as determined from $\delta^{13} \mathrm{C}$ signatures of Anonyx nugax (Fisk et al. 2003); however, this may vary with the location and characteristics (e.g. depth) of the region. The $\delta^{13} \mathrm{C}$ signature expresses the stable carbon isotope ratio $\left({ }^{13} \mathrm{C}:{ }^{12} \mathrm{C}\right)$, which can be used to distinguish between pelagic and benthic feeding (Lawson \& Hobson 2000). A comparison of data from pelagic and benthic fauna showed signatures of $A$. nugax to be more in accordance with the $\delta^{13} \mathrm{C}$ signatures of pelagic organisms than to those of other benthic organisms (Fisk et al. 2003). This indicates a diet of pelagic organisms. Since most amphipods in our study were collected from the bottom, carrion is the most likely 'pelagic' food source. Feeding on animals at higher trophic levels is implied by the high concentrations of OCs in the benthic amphipods, which are as high as, or even higher, than levels found in seals and black guillemot (Vorkamp et al. 2004). Other studies have suggested that, in certain periods, the food source for 
amphipods is sinking zooplankton that has died of osmotic shock caused by melting ice (Legeżyńska 2001, Zajączkowski \& Legeżyńska 2001). This could also account for the more pelagic $\delta^{13} \mathrm{C}$ signature, but does not explain the elevated levels of OCs.

Age-related bioaccumulation of contaminants may contribute to elevated OC concentrations of long-lived benthic amphipods (Hargrave et al. 1992). In the present study, it was assumed that the size of the amphipods could be used to represent age. No relationship between the size of Eurythenes gryllus and concentrations of $\Sigma \mathrm{DDT}, \Sigma \mathrm{PCB}, \Sigma \mathrm{PBDE}$ and $\Sigma \mathrm{PAH}$ was observed. This suggests that, in comparison with other invertebrates and high trophic level mammals and seabirds, high OC concentrations in benthic amphipods are due to consumption of a highly contaminated diet source that is independent of the amphipods' body size, at least within the size range studied.

$\mathrm{HCH}$ concentrations in amphipods were higher in the Canadian than in the Norwegian Arctic. Higher concentrations of $\mathrm{HCH}$, especially $\alpha-\mathrm{HCH}$, were generally found in the Canadian compared with the Norwegian Artic (Fisk et al. 2003). This difference was attributed to different water masses, distances to sources, and variations in ice-cover (Muir et al. 1999).

Based on the relative composition of $\mathrm{HCH}$ and $\mathrm{PCB}$, Anonyx nugax (particularly that from NBB) seems to be feeding at a lower trophic level in the food web compared with Paramphitoe hystrix and Eurythenes gryllus. The relative contribution of $\alpha-\mathrm{HCH}$ to $\Sigma \mathrm{HCH}$ decreases up the marine food web, whereas the relative contribution of $\beta-\mathrm{HCH}$ increases (Moisey et al. 2001). Thus, the higher contribution of $\beta-\mathrm{HCH}$ to $\mathrm{HCH}$ in P. hystrix and E. gryllus compared with $A$. nugax may indicate that the former are feeding on animals at higher trophic levels than the latter, or that the $\alpha-\mathrm{HCH}$ exposure is higher in the Canadian Arctic. Similarly, the PCB pattern changes through the food web, with the relative contribution of recalcitrant congeners such as CB 153 increasing with trophic level (Bright et al. 1995). Therefore, because A. nugax (RB) has the same relative contribution of CB 153 as E. gryllus and $P$. hystrix, the difference in $\mathrm{HCH}$ pattern is likely due to the difference in $\mathrm{HCH}$ exposure between the Arctic regions. The higher relative contribution of CB 31 and lower relative contribution of $\mathrm{CB} 153$ to ¿PCB in A. nugax (NBB) compared with P. hystrix, E. gryllus and A. nugax (RB) implies that $A$. nugax (NBB) was feeding at a lower trophic level.

The absolute OC concentrations differed widely among the individual Eurythenes gryllus samples, whereas the pattern (standardized concentration) was more similar. A large variation in OC concentration indicates either a difference in exposure or individual variance in bioaccumulation (e.g. due to age or trophic level), while a similar pattern indicates similar exposure or selective elimination of OCs. Since the OC concentrations were not related to the amphipod's size, the relatively high variation in concentration between the amphipods from the same location (Fig. 1a) supports the hypothesis that amphipods are scavengers.

The largest difference in the OC pattern between ringed seal and amphipods is the higher contribution of the more persistent $\beta-\mathrm{HCH}$ to $\mathrm{\Sigma HCH}$ in ringed seal. This difference indicates that, even though the benthic amphipods are carrion feeders, they do not feed predominantly on seals, because this would be expected to lead to higher contribution of $\beta-\mathrm{HCH}$. However, the OC concentrations in the amphipods were observed at the same concentrations as in seals. The likely explanation for these high concentrations in amphipods is feeding on organisms high in the food chain.

\section{Bioaccumulation of PBDEs and PAHs in Eurythenes gryllus}

As with PCB and DDT, the amounts of PBDEs found in Eurythenes gryllus were high compared with levels previously observed in marine animals: the PBDE levels were 5 to 10 times higher than in ringed seals from the Canadian Arctic (Ikonomou et al. 2002), and in the same magnitude as ringed seals from East Greenland (Vorkamp et al. 2004). The levels of PBDEs in Eurythenes gryllus where 100 to 150 times higher than in blue mussels from southern Greenland (Christensen et al. 2002). The PBDE pattern was similar to that found in both seals and blue mussels, with BDE47 being the dominant compound. However, HBCD was not investigated in the previous studies of mussels and seals. So far, HBCD has only been found in a limited number of biota samples from the Arctic, such as polar bears Ursus maritimus (Muir et al. 2006), but no results have been published for benthic organisms. Concentrations in the benthic amphipods are approximately 100-fold lower than the levels found in polar bears from the Svalbard area (Muir et al. 2006), but are in the same range as those in glaucous gulls Larus hyperboreus from the Norwegian Arctic (Verreault et al. 2005). HBCD has increased in the environment over the latest $20 \mathrm{yr}$ (de Wit 2002), and is now found in biota from several European countries (Heeb et al. 2005). Whether the new occurrence of HBCD in amphipods is due to increasing concentrations in the environment or due to the lack of measurements of HBCD in earlier Arctic samples is difficult to say, but the fact that the levels are the same as those found in gulls supports the hypothesis that amphipods feed high in the food chain. 
The positive correlation among $\Sigma$ PCB, $\Sigma D D T$ and $\Sigma$ BFR indicates a similar bioaccumulation potential among these groups of OCs. A similar relationship among OCs was also found for ringed seal and Arctic char Salvelinus alpinus (Vorkamp et al. 2004). As for $\Sigma$ PCB and $\Sigma D D T$, there was no relationship between the size of the amphipod and $\Sigma$ PBDE concentration. The lack of a relationship could be due to an increase in ambient PBDE concentration over the last decades that lead to similar PBDE burdens in all age groups, as found in ringed seals (Ikonomou et al. 2002). This is, however, not likely for the benthic amphipods, because the positive correlation among PCBs, DDTs and BFRs suggests that these compound groups behave similarly in the marine invertebrates and that they most likely have a similar source-carrion from the pelagic zone.

The PAH levels in Eurythenes gryllus were 1.5 to 10 times higher than in other amphipods from other Arctic regions (Steinhauer \& Boehm 1992, AMAP 1998). Relative to what was found in mussels from the area around a former gas plant (Law et al. 2002), the amphipods' $\Sigma$ PAH were generally 2 to 30 times lower; however, the concentrations of some PAHs in E. gryllus were at the same level or even higher (chrysene, indeno[123cd]pyrene and benzo[ghi]perylene). The PAHs have a low bioaccumulation potential (Muir et al. 1992) and bioaccumulate to a lesser degree than organochlorines in fish and invertebrates (Macdonald et al. 2000). The lower bioaccumulation potential was reflected in the lack of correlation among PCBs, DDTs and PAHs.

\section{CONCLUSION}

High OC concentrations in benthic amphipods collected from various Arctic locations support earlier suggestions that the investigated benthic amphipods are scavengers that feed on carrion. That relatively small benthic animals contain such high levels of pollutants reveals the necessity for a certain amount of knowledge on the biology of an animal before it can be used as a tracer of pollution in a given area, because benthic animals will normally be viewed as species at the bottom of the food chain and thereby as containing low amounts of pollutants.

Acknowledgements. We thank E. Sverko and M. Williamson, Environment Canada (Burlington, Ontario) for laboratory analyses, and K. Bach for helpful comments.

\section{LITERATURE CITED}

AMAP (Arctic Monitoring and Assessment Program) (1998) AMAP assesment report: Arctic pollution issues. AMAP, Oslo
Bernhoft A, Skaare JU (1994) Levels of selected individual polychlorinated biphenyls in different tissues of harbour seals (Phoca vitulina) from the southern coast of Norway. Environ Pollut 86:99-108

Bidleman TF, Walla MD, Muir DCG, Stern GA (1993) Selective accumulation of polychlorocamphenes in aquatic biota from the Canadian Arctic. Environ Toxicol Chem 12: 701-709

Borgå K, Bidleman TF (2005) Enantiomer fractions of organic chlorinated pesticides in Arctic marine ice fauna, zooplankton, and benthos. Environ Sci Technol 39:3464-3473

Borgå K, Gabrielsen GW, Skaare JU (2002) Differences in contamination load between pelagic and sympagic invertebrates in the Arctic Marginal Ice Zone: influence of habitat, diet and geography. Mar Ecol Prog Ser 235: $157-169$

Bowes GW, Jonkel CJ (1975) Presence and distribution of polychlorinated biphenyls (PCB) in Arctic and Subarctic marine food chains. J Fish Res Board Can 32:2111-2123

Brevik EM (1978) Gas chromatographic method for the determination of organochlorine pesticides in human milk. Bull Environ Contam Toxicol 19:281-286

Bright DA, Grundy SL, Reimer KJ (1995) Differential bioaccumulation of non-ortho-substituted and other PCB congeners in coastal arctic invertebrates and fish. Environ Sci Technol 29:2504-2512

Broman D, Naf C, Zebuhr Y (1992) Occurence and dynamics of polychlorinated dibenzo-para-dioxins and dibenzofurans and other combustion related organic pollutants in the aquatic environment of the Baltic. Chemosphere 25: $125-128$

Charmasson SS, Calmet DP (1987) Distribution of scavenging Lysianassidae amphipods E. gryllus in the northeast Atlantic: comparison with studies held in the Pacific. Deep-Sea Res 4:1509-1523

Christensen JH, Glasius M, Pécseli M, Platz J, Pritzl G (2002) Polybrominated diphenyl ethers (PBDEs) in marine fish and blue mussels from southern Greenland. Chemosphere 47:631-638

Cleeman M, Riget F, Paulsen GB, Klungsøyr J, Dietz R (2000) Organochlorines in Greenland marine fish, mussels and sediments. Sci Total Environ 245:87-102

de Wit CA (2002) An overview of brominated flame retardants in the environment. Chemosphere 46:583-624

Environment Canada (1998) Manual of analytical methods, Vol 3: Organics. Environment Canada, Burlington

Fisk AT, Holst M, Hobson KA, Duffe J, Moisey J, Norstrom RJ (2002) Persistent organochlorine contaminants and enantiomeric signatures of chiral pollutants in ringed seals (Phoca hispida) collected on the east and west side of the Northwater Polynya, Canadian Arctic. Arch Environ Contam Toxicol 42:118-126

Fisk AT, Hoekstra PF, Gagnon JM, Duffe J, Norstrom RJ, Hobson KA, Kwan M, Muir DCG (2003) Influence of habitat, trophic ecology and lipids on, and spatial trends of, organochlorine contaminants in Arctic marine invertebrates. Mar Ecol Prog Ser 262:201-214

Hargrave BT (1985) Feeding rates of abyssal scavenging amphipods (Eurythenes gryllus) determined by time-lapse photography. Deep-Sea Res 29:953-961

Hargrave BT, Harding GC, Vass WP, Erickson PE, Fowler BR, Scott C (1992) Organochlorine pesticides and polychlorinated-biphenyls in the Arctic Ocean food web. Arch Environ Contam Toxicol 22:41-54

Hargrave BT, NJ Prouse, GA Phillips, PJ Cranford (1994) Meal size and sustenance time in the deep-sea amphipod Eurythenes gryllus collected from the Arctic Ocean. Deep- 
Sea Res 41:1489-1508

Hargrave BT, Phillips GA, Prouse NJ, Cranford PJ (1995) Rapid digestion and assimilation of bait by the deepsea amphipod Eurythenes gryllus. Deep-Sea Res 42: 1905-1921

Hargrave BT, Phillips GA, Vass PW, Bruecker P, Welch HE, Siferd TD (2000) Seasonality in bioaccumulation in lower trophic level Arctic marine biota. Environ Sci Technol 34: 980-987

Heeb NV, Schweizer WB, Kohler M, Gerecke AC (2005) Structure elucidation of hexabromocyclododecanes-a class of compounds with a complex stereochemistry. Chemosphere 61:65-73

Ikonomou MG, Rayne S, Addison RF (2002) Exponential Increases of the brominated flame retardents, polybrominated diphenyl ethers, in the Canadian Arctic from 1981 to 2000. Environ Sci Technol 36:1886-1892

Johansen PD, Muir DCG, Asmund F, Riget F (2004) Contaminants in traditional Greenland diet. Report to the Denmark Department of Environment. National Environmental Research Institute, Roskilde

Law RJ, Kelly CA, Baker KL, Langford KH, Bartlett T (2002) Polycyclic aromatic hydrocarbons in sediments, mussels and crustacean around a former gasworks site in Shoreham-by-Sea, UK. Mar Pollut Bull 44:903-911

Lawson JW, Hobson KA (2000) Diet of harp seals (Pagophilus groenlandicus) in nearshore-northeast Newfoundland: inferences from stable-carbon $\left(\delta^{13} \mathrm{C}\right)$ and nitrogen $\left(\delta^{15} \mathrm{~N}\right)$ isotope analysis. Mar Mamm Sci 16:578-591

Lee KT, Tanabe S, Koh CH (2000) Distribution of organochlorine pesticides in sediments from Kyeonggi Bay and nearby areas, Korea. Environ Pollut 114:207-213

Legeżyńska J (2001) Distribution patterns and feeding strategies of lysianassoid amphipods in shallow waters of an Arctic fjord. Pol Polar Res 22:173-186.

Luross JM, Alaee M, Sergeant DB, Cannon CM, Whittle DM, Solomon KR, Muir DCG (2002) Spatial distribution of polybrominated diphenyl ethers and polybrominated biphenyls in lake trout from the Laurentian Great Lakes. Chemosphere 46:665-672

Macdonald RW, Barrie LA, Bidleman TF, Diamond ML and 25 others (2000) Contaminants in the Canadian Arctic: 5 years of progress in understanding sources, occurrence and pathways. Sci Total Environ 254:93-234

Moisey J, Fisk AT, Hobson KA, (2001) Hexachlorocyclohexane $(\mathrm{HCH})$ isomers and chiral signatures of a $\alpha-\mathrm{HCH}$ in the Arctic marine food web of the Northwater Polynya. Environ Sci Technol 35:1920-1927

Muir DCG, Wagamann R, Hargrave BT, Thomas DJ, Peakall DB, Norstrom RJ (1992) Arctic marine ecosystem contamination. Sci Total Environ 122:75-134

Editorial responsibility: Howard Browman (Associate Editorin-Chief), Storebø, Norway
Muir DCG, Braune B, DeMarch D, Norstrom R and 7 others (1999) Spatial and temporal trends and effects of contaminants in the Canadian Arctic marine ecosystem: a review. Sci Total Environ 230:83-144

Muir DCG, Backus S, Derocher AE, Dietz R and 8 others (2006) Brominated flame retardants in polar bears (Ursus maritimus) from Alaska, the Canadian Arctic, East Greenland, and Svalbard. Environ. Sci Technol 40:449-455

Oliver JS, Slattery PN (1985) Destruction and opportunity on the sea floor: effects of gray whale feeding. Ecology 66: 1965-1975

Sainte-Marie B (1992) Foraging of scavenging deep-sea lysianassoid amphipods. In: Rowe GT, Parriente V (eds) Deep-sea food chains and global carbon cycle. Kluwer Academic, Dordrecht, p 105-124

Schnabel KE, Hebert PDN (2003) Resource-associated divergence in the arctic marine amphipod Paramphithoe hystrix. Mar Biol 143:851-857

Steinhauer MS, Boehm PB (1992) The composition and distribution of saturated and aromatic hydrocarbons in nearshore sediments, river sediments and coastal peat of the Alaskan Beaufort Sea: implications for detecting anthropogenic hydrocarbon inputs. Mar Environ Res 33:223-53

Stokker YD (2000) Northern contaminant program interlaboratory quality assurance program for 1999-2000. In: Kalhok S (ed) Synopsis of research conducted under the 1999-2000 Northern Contaminants Program. Indian and Northern Affairs Canada, Ottawa, p 329-339

Stokker YD (2001) Northern contaminant program interlaboratory quality assurance program for 2000-2001. In: Kalhok S (ed) Synopsis of research conducted under the 1999-2000 Northern Contaminants Program. Indian and Northern Affairs Canada, Ottawa, p 364-371

Ter Braak CJF, Smilauer P (1998) CANOCO reference manual and user's guide to CANOCO for Windows: software for CANOCO community ordination, version 4. Microcomputer Power, Ithaca, NY

Verreault J, Gabrielsen GW, Shaogang C (2005) Flame retardants and methoxylated and hydroxylated polybrominated diphenyl ethers in two Norwegian Arctic top predators: glaucous gulls and polar bears. Environ Sci Technol 39:6021-6028

Vorkamp K, Christensen JH, Riget F (2004) Polybrominated diphenyl ethers and organochlorine compounds in the biota from the marine environment of East Greenland. Sci Total Environ 331:143-155

Węslawski JM, Legeżyńska J (2002) Life cycles of some arctic amphipods. Pol Polar Res 23:253-264

Zajączkowski M, Legeżyńska J (2001) Estimation of zooplankton mortality caused by an Arctic glacier outflow. Oceanologia 43:341-351

Submitted: July 18, 2006; Accepted: October 30, 2006 Proofs received from author(s): April 26, 2007 